\title{
Determining Phytocomponents of Vetiver Grass (Chrysopogon zizanioides) Under Drought Stress
}

\author{
ANI SULISTIYANI ${ }^{1}$, SYAMSUL FALAH $^{2}$, TRIADIATI $^{3 *}$ \\ ${ }^{1}$ Plant Biology Graduate Program, Department of Biology, Faculty of Mathematics and Natural Sciences, \\ IPB University \\ J1. Agatis, Gedung Biologi, Kampus IPB, Dramaga, West Java, Indonesia. 16680 \\ ${ }^{2}$ Department of Biochemistry, Faculty of Mathematics and Natural Sciences, IPB University \\ Jl. Tanjung, Gedung Biokimia, Kampus IPB Dramaga Bogor, West Java, Indonesia. 16680 \\ ${ }^{3}$ Department of Biology, Faculty of Mathematics and Natural Sciences, IPB University \\ Jl. Agatis, Gedung Biologi, Kampus IPB Dramaga Bogor, West Java, Indonesia. 16680 \\ *Email: adiatiipb@gmail.com
}

Received 23 December 2019; Received in revised form 23 April 2020;

Accepted 17 May 2020; Available online 30 June 2020

\begin{abstract}
Vetiver grass (Chrysopogon zizanioides), Poaceae is the leading commodity in Garut Regency, Indonesia, the second-largest producer in the world of vetiver oils. The content of vetiver oils is strongly influenced by the environment, for example, drought stress. Drought stress causes plants to adapt by producing secondary metabolites such as essential oils. This experiment aimed to analyze growth, phytocomponents and obtaining the best quality of vetiver grass accessions under drought stress. The results showed that root and shoot dry biomass were significantly affected by the interaction between drought stress duration and vetiver grass accession. The root dry biomass of Kamojang accession decreased by $25.4 \%$, while Cilawu increased by $5 \%$ for four days of drought stress. The root length and shoot length were not significantly affected by the treatment. The highest root/shoot length ratio was Verina, and the lowest one was Cisarua. The highest increase in proline occurred in Cilawu accession (85.7\%), while the lowest was Verina (6.67\%). Essential root oils contain 53 types of phytocomponents, dominated by sesquiterpenes, being khusimol, the highest type. The Cilawu is the best accession based on growth and content rendement.
\end{abstract}

Keywords: drought stress; essential oil; khusimol, proline; vetiver oils

\section{INTRODUCTION}

Chrysopogon zizanioides L. (vetiver grass) synonymously known as Vetiveria zizanioides L. belongs to family Poaceae, widely cultivated in the tropical regions of the world. Some of their common names are Khus-khus (India), Khas Khas grass (Africa), Vetiver (Europe), and Akar Wangi (Java). Vetiver grass requires adequate rainfall, which is around 140 days per year, while the suitable temperature is around $17-27^{\circ} \mathrm{C}$. It grows at an altitude of about 300 2000 masl (Jariyah \& Supangat, 2008). Vetiver grass is a miraculous species native to India, first used for soil and water conservation, and now a source of secondary metabolites, known as vetiver oils. Vetiver oils are used in cosmetic and aromatherapy industries (Bhushan et al., 2013).

Indonesia was the second-largest producer of vetiver oils in the world after Haiti in 2010 (Kadarohman et al., 2014). Indonesia's exports of this oil reach a quarter of total world production (80 tons), estimated at 300 tons each year. Vetiver oils for Indonesia are one of the commodity sources of state revenue (BAPPEBTI, 2014). Vetiver grass that originates from South India spread to Sri Lanka, Burma, Bangladesh, and Southeast Asia (Pareek \& Kumar, 2013), including Indonesia, centered in Garut Regency, West Java. In Garut, the vetiver glass cultivation and production centers are located in Cilawu, Vayongbong, Samarang, Pasrwangi, and Leles (DISKOMINFO, 2017). Garut Regency has sandy volcanic soils produced by active volcanoes in the surroundings. It is a suitable feature for vetiver grass (PEMDA KAB. GARUT, 2014) since it is found in areas with sandy soils and unstable rainfall. Most Indonesia regions have a dry season that can cause drought and are not beneficial for vetiver grass. It increases free radical compounds that 
damage to plant cells, thereby resulting in decreased plant productivity.

The availability of water in the soil is an important factor for the growth, so drought is a limiting factor of vetiver oils. On the other side, environmental stress can be used as a strategy to optimize the production of phytocomponents in some plants. Environmental factors such as drought can increase secondary metabolites in plants (Chen et al., 2011; Queiroz et al., 2019), some drought-tolerant plants will adapt by producing secondary metabolites to prevent tissue damage and repair plant cells (Gu et al., 2010; Kumari \& Agrawal, 2010).

A phytocomponent is a plant secondary metabolite used for defense against pathogens (Shaba et al., 2014; Orieke et al., 2018; Mamani \& Alhaji, 2019), adaptation against environmental stresses and UV light (Deepa et al., 2019; Chikezie et al., 2020), and phytocomponents including polyphenols play a role as a growth regulator (Khan et al., 2018; Ovais et al., 2018; Jha et al., 2019). Parts of these plants that contain oil are the roots, while other parts such as stems and leaves do not contain oil. Vetiver grass has pale yellow or gray roots to dark red and contains essential oils with a fragrant and long-lasting aroma.

Anatomically these oils are found in secretory cells located between the vetiver grass root cortex and endodermis (Mulyono et al., 2012). Cortical thickness is related to the storage capacity of water and oil in the roots. Increasing the number of cells in the cortex increases plant tolerance to drought stress (Estrada-Melo et al., 2015). More plants develop root systems during drought, and more increase secondary metabolites production in plants to respond to drought stress (Lynch \& Brown, 2012).

Garut is an area that has a dry season lasting three months every year (August to October). The possibility of rain during these months is 0-2 days. This period is the most stressful in terms of drought stress for plants (Mulyono et al., 2012). The information about the drought stress effect on the growth and production of vetiver grass oil, especially from Garut Regency, is very limited, so accession of vetiver grass from Garut based on different highlands was used. Line with Dacosta et al. (2017), essential oil of lemongrass from Bedugul plateau was higher than Denpasar lowland area. Therefore, research on the effect of drought stress on vetiver grass's growth and oil production needs to be done. This study is expected to obtain data on growth, oil production, and phytocomponents of the vetiver grass under drought stress. This research also found the best accession based on growth parameters and oil production.

\section{MATERIALS AND METHODS}

Study area. The study was conducted in August 2018 to March 2019 at IPB University, Laboratory of Plant Physiology and Genetics, Department of Biology, Faculty of Mathematics and Natural Sciences, Research Institute for Medicinal and Spices Plants (Balittro), and the Regional Health Laboratory (Labkesda) Jakarta.

The experimental design. The experimental design. This study using a factorial randomized block design. The first factor was the accessions. Three accessions came from Garut Regency, which shows altitudinal variations: accession 1 from Cisarua (1000 masl), accession 2 from Kamojang (1400 masl), accession 3 from Cilawu (1200 masl). Accession 4 is from Verina. The second factor was the duration of drought, consisting of four levels: 0, 4, 8, and 12 days of drought. The vetiver grass accessions were adapted for 5 months using watering capacity until they have the same growth. Dried stems and leaves were removed to enhance new leaves' growth, and plants were kept free from weeds. The treatment of drought stress is carried out with a different duration determined for 3 months. Plant growth parameters measured were root length $(\mathrm{cm})$, shoot length $(\mathrm{cm})$, root dry biomass (g), and shoot dry biomass (g)(Setiawan et al., 2012). Root and shoot dry biomass were measured after being roasted for four days in the oven at $70^{\circ} \mathrm{C}$, while root and shoot length were measured using a bar.

Proline Analysis. The proline content was analyzed to determine the effect of drought stress on plant growth. A total of $0.5 \mathrm{~g}$ of fresh leaves were crushed in a mortar, adding $10 \mathrm{ml}$ 
of $3 \%$ sulfosalicylic solution. The aliquot ground leaves were filtered with Whatman filter paper, from which $2 \mathrm{ml}$ of filtrate was mixed with $2 \mathrm{ml}$ of ninhydrin acid and $2 \mathrm{ml}$ of glacial acetic acid at $100^{\circ} \mathrm{C}$ for 1 hour. The reaction ended by inserting the test tube into a piece of ice. The ninhydrin acid solution was prepared by heating $1.25 \mathrm{~g}$ of ninhydrin in $30 \mathrm{ml}$ of glacial acetic acid and $20 \mathrm{ml} 6 \mathrm{M}$ phosphoric acid until it dissolves. The mixture was extracted with $4 \mathrm{ml}$ of toluene, then shake with vortex for 15-20 $\mathrm{s}$ to form two separate liquid layers. The red color of the solution containing proline was at the top. The proline content was measured with a spectrophotometer at a wavelength of $520 \mathrm{~nm}$. The proline content was determined based on a standard pure proline solution (Umebese et al., 2009).

The distillation method for oil extraction is based on SNI 01-0005-1995 by weighing $40 \mathrm{~g}$ of root pieces and put in a boiling flask. Water was added until all the root samples are submerged and adding some boiling stones. The boiling flask was connected with the DeanStark distillation, and the tube was heated. Distillation was stopped if no more drops of oil drip. Identification of the phytocomponents of vetiver grass oil was carried out with GC-MS (Gas Chromatography-Mass Spectrometry) at the Regional Health Laboratory, Jakarta. The extract $(3 \mu \mathrm{l})$ was injected in a GC-MS (Model 5975, Agilent Technologies, Palo Alto, USA), connected to a Mass Selective Detector and a Chemstation Data System. The HP ultra 2 capillary column $(0.11 \mu \mathrm{m})$ was used in this analysis. The instrument for analysis was set as follows: injection temperature $\left(250^{\circ} \mathrm{C}\right)$. Helium was used as carrier gas with a flow rate of 1.2 $\mathrm{ml} / \mathrm{min}$. The mass spectrum was detected in a mass-toe 1682829 - charge range of $20-500 \mathrm{~m} / \mathrm{z}$. Metabolite identification was performed based on the Wiley W8N08.L database.

Oil rendement of vetiver grass oil was calculated using the following equation:

$$
\text { Rendement }(\%)=\frac{\text { weight of oil }(\mathrm{gr})}{\text { root dry weight }(\mathrm{gr})} \times 100 \%
$$

Data analysis. Growth data and proline were analyzed by ANOVA and continued with DMRT analysis at $\alpha=5 \%$ using SPSS 25.0.
Phytocomponent was analyzed using metaboanalyst 4 and identified for their group compound based on online databases, i.e., ChemSpider (http://www. chemspider.com/), Pubchem (https://pubchem.ncbi.nlm.nih.gov/), and

CAMEO (https://cameochemicals.noaa.gov/) (Turhadi et al., 2019).

\section{RESULT AND DISCUSSION}

Growth Responses. Root and shoot dry biomass were significantly affected by the interaction between drought stress duration and accessions $(p<0.05)$. Although the effect of drought stress on growth was not significant, it has a different effect on each accession's growth in each duration of drought stress. Root dry biomass of day 4 drought stress decreased in all accessions except on Cilawu accessions. The biggest decrease of root dry biomass occurred in Kamojang accessions by $25.4 \%$, while Cilawu accessions increased by $5 \%$. Shoot dry biomass of all accessions decreased on the drought stress of day 8, except shoot dry biomass of Verina decreased on drought stress day 4 by $24.4 \%$.

Drought stress severely affected Verina dry biomass, while Cilawu accession experienced the lowest decrease by $8.6 \%$. Root and shoot length were not affected by the interaction between drought stress duration and accessions ( $p>0.05$ ). The highest addition of root length was Verina by $29 \%$ of day 4 , as well as the addition of the highest shoot length by $4.39 \%$ of day 12, and the lowest was Cisarua by $0.36 \%$ (Figure 1). However, both parameters have a reverse pattern. Root length of most accessions increased, and shoot length decreased on day 4, while root length decreased, and shoot length increased on day 8 of drought stress.

Root and shoot dry biomass were influenced by the interaction between drought stress and accessions because dry biomass was closely related to the primary metabolism. This plant also produced secondary metabolites for self-defense when facing stress. It is thought that the production of primary metabolites from these plants was allocated to produce secondary metabolites such as oil. Therefore, when drought stress occurs, it significantly influences 
decreased root and shoots dry biomass. Nevertheless, root and shoot dry biomass decreased are thought to indicate each accession's adaptability to different duration of drought stress. In this case, the best accession was Cilawu, and the one that is less able to adapt to drought was Verina. Drought stress can
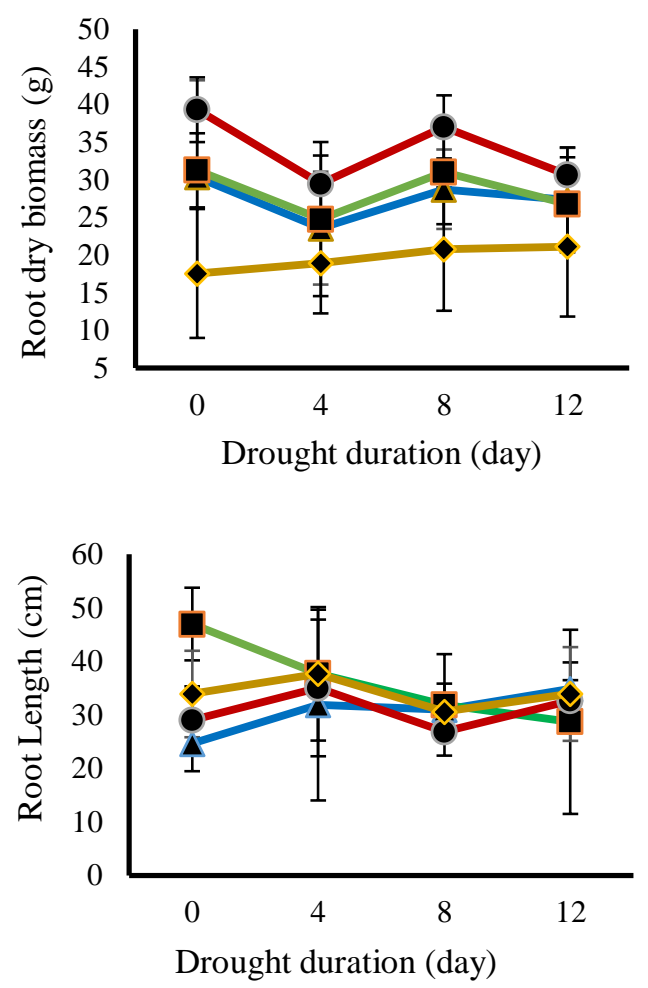

reduce plants' productivity due to decreased primary metabolism, biomass loss of leaves, and photosynthetic activity. The decrease in biomass accumulation due to drought stress for each plant type is not of the same magnitude. This is influenced by the response of each type of plant.
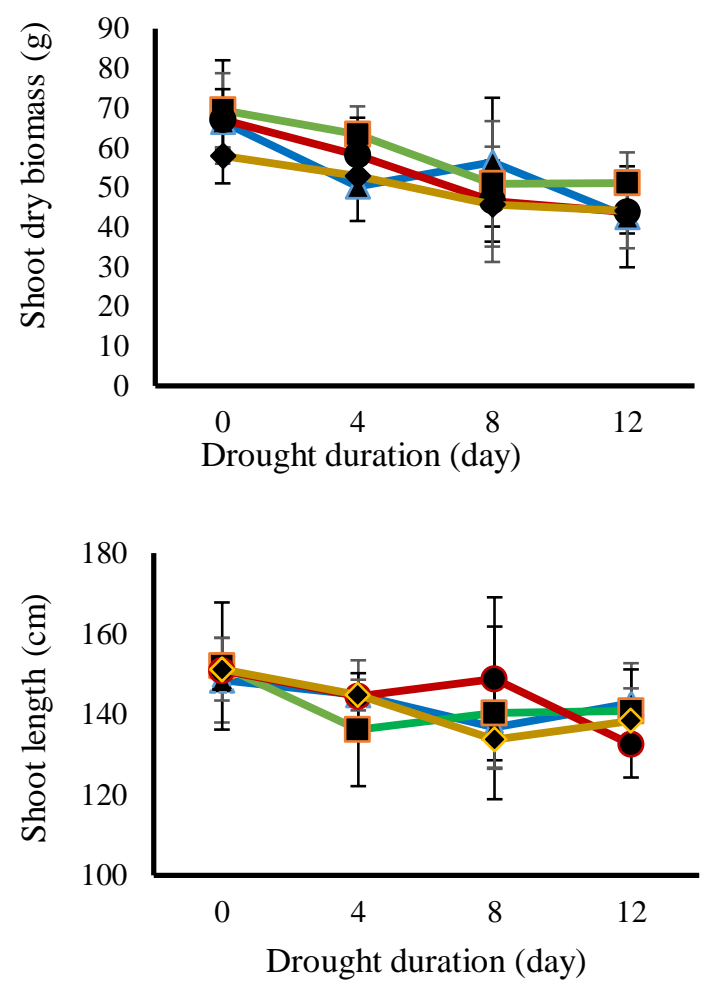

Figure 1. Vetiver grass growth on parameters: a. root dry biomass; b. shoot dry biomass; c. root length; d. shoot length during drought stress of day $0,4,8$, and 12. Bar lines indicate standard deviations

The root and shoot length were not significantly influenced by the interaction between drought stress and type of accession because vetiver grass is a plant that can tolerate various environmental pressures, such as drought stress, compared to other plants such as corn (Zea mays L.) and sugar cane (Saccharum officinarum)(Darajeh et al., 2019). So even if drought stress during 12 days did not significantly affect the root and shoot length, the ratio of root and shoot length can be used as an indicator of vetiver grass adaptation to water shortage, which is comparable with research on the response of sugarcane to drought stress in which the increase in root length and reduced leaf size in drought stress $50 \%$ higher than normal conditions. Drought stress was suspected of causing the assimilation produced in the photosynthesis process to be lower because the water needed for the photosynthesis process is available in limited quantities. As a result, the assimilate translocation to the root and shoot is also small, resulting in low root and shoot dry biomass. Whereas the root length and shoot length parameters showed an inverted pattern, it is expected that most of the photosynthetic assimilate from the roots are allocated, as a form of plant strategy will be able to absorb water more optimally and nutrients.

However, if water conditions are inadequate (of day 12 drought stress), then the length of the root and shoot decreases, and the root and shoot dry biomass still decreases. Water absorption and minimum osmotic pressure cause plants to increase deep root growth and spread (Wasson et al., 2012; Madhu \& Hatfield, 2013). The mechanism of plants to 
avoid drought stress is to extend the roots to find water sources that are relatively far from the drought (Abd Allah et al., 2010). Farooq et al. (2009) also stated that the effects of drought on plants were a rise in dry matter allocation to roots, increased membrane lipid peroxidation, ease leaf development, and decreased biomass production.

Proline Content. The proline content was not influenced by the interaction between drought stress duration and accession ( $p>0.05)$.
Proline content in Kamojang and Verina began to increase on day 4, while Cilawu and Cisarua on day 12 (Figure 2). The highest increase in proline was found in Cilawu accession by $85.7 \%$, while the lowest was Verina by $6.67 \%$ on day 4 of drought stress. Proline content in Kamojang accessions on day 12 possibly caused by metabolism in the plant cells that have been disrupted, so proline was not produced in the plant cells.

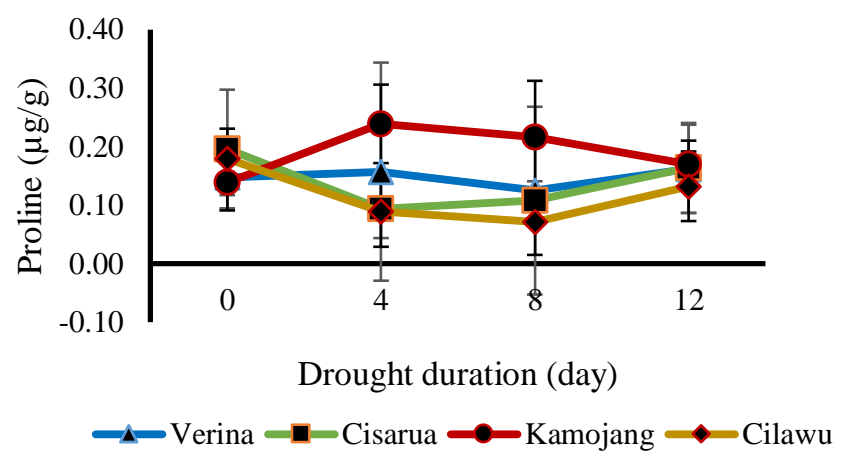

Figure 2. Proline content during drought stress of day 0, 4, 8, and 12. Bar lines indicate standard deviations

The four accessions of vetiver grass had increased proline in different amounts so that the level of plant resistance was thought to be different. The increase in proline is thought to be an adaptation effort by vetiver grass from drought stress. Comparable studies on 14 sugarcane genotypes treated with drought stress showed an increase of $0.4-1.6 \mu \mathrm{g} / \mathrm{g}$ from normal conditions (Medeiros et al., 2015). Related to the duration of drought stress, Cilawu accession was thought to have better adaptability than other accessions because it can produce higher proline than others. Dedemo et al. (2013) stated that plants would begin to accumulate amino acid proline when gripped by drought and begin to adapt by stabilizing membrane proteins. The way plants regulate osmotic pressure when faced with drought is thought to be an adaptive process, with the production of proline in cells, thereby reducing osmotic potential when water deficits occur, so plasmolysis does not occur. The results of this osmotic regulation are turgor pressure, which is maintained above zero. Thus, the process of cell division continues and avoids wilting that can harm cells. Proline accumulation results from an increase in free amino acids when plants are in a stressful environment, such as drought. In line with Per et al. (2017), proline is one of the strategies responses of plants to drought and salt stress.

The relation between duration of stress to the growth and production of oils, based on growth patterns (Figure 1) and proline content (Figure 2) of vetiver grass, is suspected that this plant began to be gripped the duration of drought stress of day 4 . It is indicated by root dry biomass and shoot size decreases. However, plants began to adapt by improving themselves on day 8 , which was marked by increasing the dry biomass of the roots and shoot again, but on day 12 drought stress the plants could no longer withstand the drought stress so that the dry biomass of the roots and shoot decreased dramatically. The same is addressed by the root and shoot length. The root length increases of day 4 drought stress, which can be used to determine that the vetiver grass begins to be seized of day 4 drought stress. Proline is starting to increase, which indicates that the cell is in a self-repairing stage.

Oil Production. The oil volume of vetiver grass accessions decreased on day 4 , increased on day 8 , and decreased on day 12 , except for Cilawu accession, which continued to increase 
since the duration of day 4 of drought stress. Cilawu accession has the highest rendement of
$0.54 \%$, and the lowest rendement is Cisarua by $0.12 \%$ (Table 1 ).

Table 1. Production of vetiver grass oil from Verina, Cisarua, Kamojang, and Cilawu using the SNI 01-0005-1995 testing method item 7.6

\begin{tabular}{|c|c|c|c|}
\hline Accession & Stress Duration (day) & Oil Volume (ml) & Rendement (\%) \\
\hline \multirow{4}{*}{ Verina } & 0 & 0.4 & 0.44 \\
\hline & 4 & 0.3 & 0.27 \\
\hline & 8 & 0.2 & 0.21 \\
\hline & 12 & 0.2 & 0.18 \\
\hline \multirow{4}{*}{ Cisarua } & 0 & 0.3 & 0.25 \\
\hline & 4 & 0.1 & 0.09 \\
\hline & 8 & 0.4 & 0.33 \\
\hline & 12 & 0.1 & 0.12 \\
\hline \multirow{4}{*}{ Kamojang } & 0 & 0.3 & 0.22 \\
\hline & 4 & 0.1 & 0.09 \\
\hline & 8 & 0.4 & 0.26 \\
\hline & 12 & 0.2 & 0.22 \\
\hline \multirow{4}{*}{ Cilawu } & 0 & 0.4 & 0.39 \\
\hline & 4 & 0.3 & 0.25 \\
\hline & 8 & 0.4 & 0.37 \\
\hline & 12 & 0.4 & 0.54 \\
\hline
\end{tabular}

The difference in the volume of oil produced from each accession with different drought stress duration explains that the oil production ability from each accession is different when in drought stress. Verina has the highest oil volume when 0 drought stress. On the other side, Cisarua and Kamojang have the highest oil volume on day 8 , Cilawu has the highest on day 12 of drought stress. In other words, Cilawu was the best accession with the highest oil volume with an increase in stress duration. Generally, the relationship of drought stress duration to the oil volume showed that day 8 drought stress produced the highest oil volume accessions and decreased day 12 drought stress. It can be assumed that of day 8 , drought stress was the best duration for watering vetiver oil during the dry season because watering above or below the duration of the stress harms the growth and production of vetiver grass oil. In line with Poaceae, Zea mays cultivar Bima 2 Bantimurung, watering interval every 8 days has decreased the dry biomass of plants and harvest production (Ciptaningtyas et al., 2014). The relationship between the duration of drought stress with oil content in vetiver grass in this research was unclear. This study contradicts García-Caparrós et al. (2019) that drought stress reduced oil content in leaves of six Lamiaceae species. Essential oils or etheric are a large group of oil in the form of viscous liquid at room temperature but are volatile, thus giving a distinctive aroma. Some essential oils are compounds that contain carbon and hydrogen, or carbon, hydrogen, and oxygen that are not aromatic (Pengelly, 2004). The Cilawu produces oil volume and rendement relatively stable and increases with the duration of stress. It is suspected that Cilawu accession is more resistant to drought stress than Verina as a control. The oil rendement from Verina decreases with the increasing duration of drought stress. This coincides with the research of Swasono et al. (2015) in citronella oil (Cymbopogon nardus), which produced higher oil rendement at $50 \%$ water field stress than the water treatment at $100 \%$ field capacity. Cilawu accession ability to withstand drought stress is suspected because it produces specific phytocomponents in its oil.

Phytocomponents. Phytocomponents in vetiver grass oil were dominated by sesquiterpenes, aromatic hydrocarbon, and phenolic groups. Phytocomponents found in all accessions treated with drought stress were 
grouped into 9 types. Sesquiterpenes dominated the phytocomponents by $45 \%$, aromatic hydrocarbons by $36 \%$, and phenolic by $8 \%$ (Figure 3). Chahal et al. (2015) described that essential oils produced by plants belonging to the genus Vetiveria mostly contain terpenes and aromatic hydrocarbons.

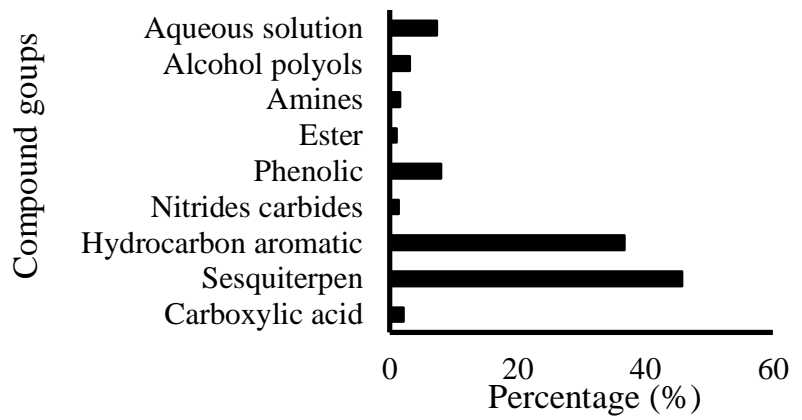

Figure 3. Phytocomponents based on its compound group. The categorization is based on various databases

Phytocomponents found in all accessions in the 8-day drought stress were from 53 types.
The highest number was khusimol $\left(\mathrm{C}_{15} \mathrm{H}_{24}\right)$ from Cisarua accession by $26.8 \%$ (Figure 4 ).

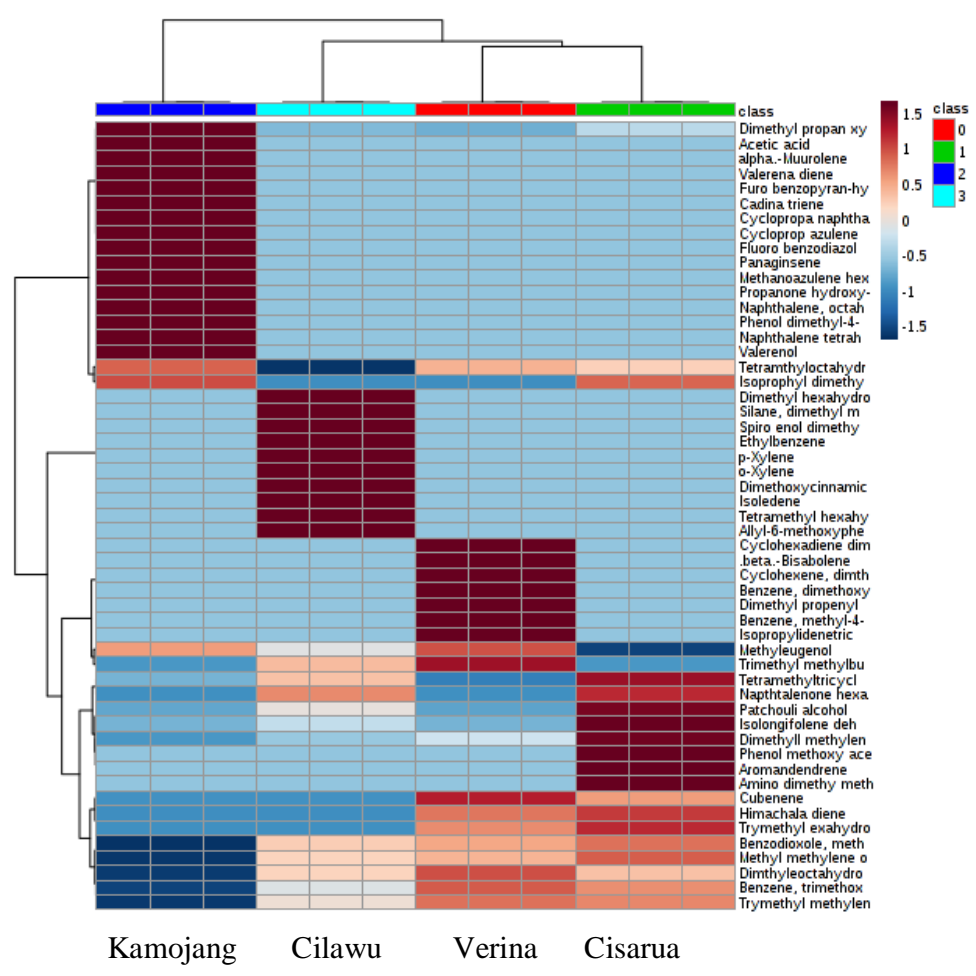

Figure 4. Phytocomponents of vetiver grass from Kamojang, Cilawu, Verina, and Cisarua accessions

The main component of vetiver oils was sesquiterpenes that provide a distinctive fragrance to vetiver grass. According to Dubey et al. (2010), the main component of vetiver grass oil in South India determines the quality of vetiver grass oil was khusimol by $16.25 \%$. Besides khusimol, beta-vetivone is another marker compound that characterizes vetiver grass (Kirici et al., 2011). In this study, betavetivone $(6.08 \%)$ was produced. In plants, terpenes provide defense functions against herbivores or environmental stress (Gil et al., 2012; Shrivastava et al., 2015). Furthermore, other high sesquiterpenes are patchouli alcohol. It was also found in vetiver grass from Cisarua by $12.35 \%$ in drought stress of 8 days. This compound is usually obtained from Pogostemon cablin and used in Indonesia's essential oil industry (Khanuja et al., 2005). These compounds include sesquiterpenes, that 
function as an indicator of self-resistance from drought. Patchouli alcohol was affected by low soil moisture and was reproduced when plants were seized with drought (Nasruddin et al., 2018).

Besides having a sesquiterpene, a compound which is a major component in essential oils of Vetiveria from France, it also contains phenolic compounds (Champagnat et al., 2008). In this research, phenolics were another group found in high numbers by $8 \%$. The highest type of phenolic compound was 2Allyl-6-methoxyphenol/o-Eugenol by $18.1 \%$ in Cilawu accessions. This compound's existence is thought to be the cause of Cilawu accession to have a better adaptation to drought stress. The phenolics function is to protect the DNA from dimerization and to damage the cell. This compound has an antioxidant activity that can increase self-defense from stress induced by free radicals (Lai \& Lim 2011). By 18.1\% from Cilawu accessions, the eugenol content is thought to provide benefits in dealing with drought stress because of the compound antioxidant properties (Thara-Saraswathi et al., 2011; Pérez-Rosés et al., 2016).

Phytocomponents of vetiver grass oils accessions have different characteristics. The complex composition of the essential oils and the variety of their constituents' chemical structures are responsible for a wide range of biological activities. In this experiment, acetic acid compound by $7.2 \%$ was only found in Kamojang, eugenol (18.1\%) was in Cilawu, benzene methyl-4-hexenyl (12.2\%) was in Verina, and isolongifolene, 9,10-dehydro$(8.71 \%)$ was in Cisarua. The origin habitat expects the differences of dominant phytocomponent of accessions. Riyadi et al. (2014) stated that the vetiver grass oil compound content from West Java produces 89 volatile compounds with the main components, including khusimol $6.87 \%$, beta-Vetivenene $5.61 \%$, beta-vetivone $3.88 \%$, alpha-Gurjunene $3.38 \%$, and alpha-vetivone $3.07 \%$. Danh et al. (2010) also informed that Brazilian vetiver grass roots contain zizanoic acid 32\%, khusimol 15\%, isovalenceno $19 \%$, alphavetivone $8 \%$, and $\beta$-vetivone $3 \%$. In contrast, the major components of vetiver oil collected from Tami India was valerenol 12\% (Bhushan et al., 2013).

\section{CONCLUSION}

Root and shoot biomass were affected by the interaction between drought stress duration and type of accession, while root and shoot length were not affected. Oil production in Cilawu accession under drought conditions was stable compared to Verina as a control. Sesquiterpenes dominated phytocomponents in vetiver grass oil, and the highest types of sesquiterpenes content are khusimol. The best accession based on growth parameters and oil rendement was Cilawu accession.

\section{REFERENCES}

Abd Allah AA, Ammar MH, Badawi AT. 2010. Screening rice genotypes for drought resistance in Egypt. Journal of Plant Breeding and Crop Science. vol 2(7): 205-215. doi: https://doi.org/10.5897/JPBCS.9000117.

BAPPEBTI. 2014. Java vetiver root oil (akar wangi).[Report]. Jakarta: Badan Pengawas Perdagangan Berjangka Komoditi. Buletin Kontrak Berjangka. http://www.bappebti.go.id./

Bhushan B, Kumar SS, Tanuja S, Lalit S, Hema A. 2013. Vetiveria zizanioides (Linn.) Nash: a pharmacological overview. International Research Journal of Pharmacy. vol 4(7): 18-20. doi: https://doi.org/10.7897/2230-8407.04704.

Chahal KK, Bhardwaj U, Kaushal S, Sandhu AK. 2015. Chemical composition and biological properties of Chrysopogon zizanioides (L.) Roberty syn. Vetiveria zizanioides (L.) Nash-A Review. Indian Journal of Natural Products and Resources. vol 6(4): 251-260.

Champagnat P, Heitz A, Carnat A, Fraisse D, Carnat AP, Lamaison JL. 2008. Flavonoids from Vetiveria zizanioides and Vetiveria nigritana (Poaceae). Biochemical Systematics and Ecology. vol 36: 6870. doi: https://doi.org/10.1016/j.bse.2007.05.015.

Chen Y, Guo Q, Liu L, Liao L, Zhu Z. 2011. Influence of fertilization and drought stress on the growth and production of secondary metabolites in Prunella vulgaris L. Journal of Medicinal Plants Research. vol 5(9): 1749-1755. doi: https://doi.org/10.5897/JMPR.9000792.

Chikezie PC, Ekeanyanwu RC, Chile-Agada AB. 2020. Phytocomponents from Anacardium occidentale, Psidium guajava, and Terminalia catappa altered membrane osmotic stability of sickle erythrocytes. Beni-Suef University Journal of Basic and Applied Sciences. vol 9(1): 1-22. doi: https://doi.org/10.1186/s43088-019-0030-z.

Ciptaningtyas DS, Indradewa D, Tohari. 2012. Pengaruh Interval Penyiraman Terhadap Pertumbuhan dan 
Hasil Empat Kultivar Jagung (Zea mays L.). Vegetalika. vol 1(4), 11-17. doi: https://doi.org/10.22146/veg.1592.

Danh LT, Truong P, Mammucari R, Foster N. 2010. Extraction of vetiver essential oil by ethanolmodified supercritical carbon dioxide. Chemical Engineering Journal. vol 165(1): 26-34. doi: https://doi.org/10.1016/j.cej.2010.08.048.

Dacosta M, Sudirga SK, Muksin IK. 2017. Perbandingan kandungan minyak atsiri tanaman sereh wangi (Cymbopogon nardus L. Rendle) yang ditanam di lokasi berbeda. Simbiosis. vol 5(1): 25-31. doi: https://doi.org/10.24843/JSIMBIOSIS.2017.v05.i0 1.p06.

Darajeh N, Truong P, Rezania S, Alizadeh H, Leung DWM. 2019. Effectiveness of vetiver grass versus other plants for phytoremediation of contaminated water. Journal of Environmental Treatment Techniques. vol 7(3): 485-500.

Dedemo GC, Rodrigues FA, Roberto PG, Neto CB, Franca SC, Zingaretti SM. 2013. Osmoprotection in sugarcane under water deficit conditions. Plant Stress. vol 7(1): 1-7.

Deepa B, Babaji HV, Hosmani JV, Alamir AWH, Mushtaq S, Raj AT, Patil S. 2019. Effect of Tinospora cordifolia-Derived Phytocomponents on Cancer: A Systematic Review. Applied Sciences. vol 9(23): 1-10. doi: https://doi.org/10.3390/app9235147.

DISKOMINFO. 2017. Minyak Akar Wangi. [Report]. Garut: Dinas Perkebunan Kabupaten Garut Jawa Barat. https://www.garutkab.go.id/.

Dubey N, Raghav CS, Gupta RL, Chhonkar SS. 2010. Chemical composition and antifungal activity of vetiver oil of North and South India against Rhizoctonia solani. Pesticide Research Journal. vol 22: 63-67.

Estrada-Melo AC, Ma C, Reid MS, Jiang CZ. 2015. Overexpression of an ABA biosynthesis gene using a stress-inducible promoter enhances drought resistance in petunia. Horticulture Research. vol 2(1): 1-9. doi: https://doi.org/10.1038/hortres.2015.13.

Farooq M, Wahid A, Kobayashi N, Fujita D, Basra SMA. 2009. Plant drought stress: effects, mechanisms and management. Agronomy for Sustainable Development. vol 29: 185-212. doi: https://doi.org/10.1051/agro:2008021.

García-Caparrós P, Romero MJ, Llanderal A, Cermeño P, Lao MT, Segura ML. 2019. Effects of drought stress on biomass, essential oil content, nutritional parameters, and costs of production in six Lamiaceae species. Water. vol 11(3): 1-12. doi: https://doi.org/10.3390/w11030573.

Gil M, Pontin M, Berli F, Bottini R, Piccoli P. 2012. Metabolism of terpenes in the response of grape (Vitis vinifera L.) leaf tissues to UV-B radiation. Phytochemistry. vol 77: 89-98. doi: https://doi.org/10.1016/j.phytochem.2011.12.011.
Gu XD, Sun MY, Zhang L, Fu HW, Cui L, Chen RZ, Zhang DW, Tian JK. 2010. UV-B induced changes in the secondary metabolites of Morus alba L. leaves. Molecules. vol 15(5): 2980-2993. doi: https://doi.org/10.3390/molecules15052980.

Jariyah NA, Supangat AB. 2008. Dilema penanaman akar wangi Vetiveria zizanoides L. Nash di kabupaten Garut. Info Hutan. vol 5(3): 261-272.

Jha AB, Purves RW, Elessawy FM, Zhang H, Vandenberg A, Warkentin TD. 2019. Polyphenolic profile of seed components of white and purple flower pea lines. Crop Science. vol 59(6): 27112719. https://doi.org/10.2135/cropsci2019.04.0279.

Kadarohman A, Dwiyanti G, Kadarusman E. 2014. Quality and chemical composition of organic and non-organic vetiver oil. Indonesian Journal of Chemistry. vol 14(1): 43-50. doi: https://doi.org/10.22146/ijc.21266.

Khan AM, Bhadauria S. 2019. Analysis of medicinally important phytocompounds from Argemone mexicana. Journal of King Saud UniversityScience. vol 31(4): 1020-1026. doi: https://doi.org/10.1016/j.jksus.2018.05.009

Khanuja SPS, Shasany AK, Pawar A, Lal RK, Darokar MP, Naqvi AA, Rajkumar S, Sundaresan V, Lal N, Kumar S. 2005. Essential oil constituents and RAPD markers to establish species relationship in Cymbopogon Spreng.(Poaceae). Biochemical Systematics and Ecology. vol 33(2): 171-186. doi: https://doi.org/10.1016/j.bse.2004.06.011.

Kirici S, Inan M, Turk M, Giray ES. 2011. To study of essential oil and agricultural properties of vetiver (Vetiveria zizanioides) in the Southeastern of Mediterranean. Advances in Environmental Biology. vol 5(2): 447-451.

Kumari R, Agrawal SB. 2010. Supplemental UV-B induced changes in leaf morphology, physiology and secondary metabolites of an Indian aromatic plant Cymbopogon citratus (DC) Staph under natural field conditions. International Journal of Environmental Studies. vol 67(5): 655-675. doi: https://doi.org/10.1080/00207233.2010.513828.

Lai H, Lim Y. 2011. Evaluation of antioxidant activities of the methanolic extracts of selected ferns in Malaysia. International Journal of Environmental Science and Development. vol 2(6): 442-447.

Lynch JP, Brown KM. 2012. New roots for agriculture: exploiting the root phenome. Philosophical Transactions of the Royal Society B: Biological Sciences. vol 367(1595): 1598-1604. doi: https://doi.org/10.1098/rstb.2011.0243.

Madhu M, Hatfield JL. 2013. Dynamics of plant root growth under increased atmospheric carbon dioxide. Agronomy Journal. vol 105(3): 657-669. doi: https://doi.org/10.2134/agronj2013.0018.

Mamani R, Alhaji NM. 2019. GC-MS analysis of phytocomponents in methanolic extract of Coleus aromaticus. Journal of Pharmacognosy and Phytochemistry. vol 8(4): 106-109. 
Medeiros MJL, Silva MMDA, Granja MMC, De Souza E Silva Junior G, Camara T, Willadino L, 2015. Effect of exogenous proline in two sugarcane genotypes grown in vitro under salt stress. Acta Biológica Colombiana. vol 20 (2): 57-63. doi: http://dx.doi.org/10.15446/abc.v20n2.42830.

Mulyono E, Sumangat D, Hidayat T. 2012. Peningkatan mutu dan efisiensi produksi minyak akar wangi melalui teknologi penyulingan dengan tekanan uap bertahap. Buletin Teknologi Pascapanen Pertanian. vol 8(1): 35-47.

Nasruddin, Harahap EM, Hanum C, Siregar LAM. 2018. Growth and yield of patchouli (Pogostemon cablin, Benth) due to mulching and method of fertilizer on rain-fed land. In IOP Conference Series: Earth and Environmental Science. vol 122(1): 1-7. doi: https://doi.org/10.1088/1755-1315/122/1/012057.

Orieke D, Ohaeri OC, Ijeh II, Ijioma SN. 2018. Identification of phytocomponents and acute toxicity evaluation of Corchorus olitorius leaf extract. European Journal of Medicinal Plants. vol 23(1): 1-16. doi: https://doi.org/10.9734/EJMP/2018/38739.

Ovais M, Khalil AT, Islam NU, Ahmad I, Ayaz M, Saravanan M, Shinwari ZK, Mukherjee S. 2018. Role of plant phytochemicals and microbial enzymes in biosynthesis of metallic nanoparticles. Applied Microbiology and Biotechnology. vol 102(16): 6799-6814. doi: https://doi.org/10.1007/s00253-018-9146-7.

Pareek A, Kumar A. 2013. Ethnobotanical and pharmaceutical uses of Vetiveria zizanioides (Linn) Nash: a medicinal plant of Rajasthan. International Journal of Life Science \& Pharma Research. vol 3(4): 12-18.

PEMDA KAB. GARUT. 2014. Rencana Pembangunan Jangka Menengah Daerah (RPJMD) Kabupaten Garut Tahun 2014-2019. [Report]. Garut: Pemerintah Kabupaten Garut. https://www.garutkab.go.id/.

Pengelly A. 2004. The constituents of medicinal plants: An introduction to the chemistry and therapeutics of herbal medicine. $2^{\text {nd }}$ Ed. New York: CABI Pub.

Per TS, Khan NA, Reddy PS, Masood A, Hasanuzzaman M, Khan MIR, Anjum NA. 2017. Approaches in modulating proline metabolism in plants for salt and drought stress tolerance: Phytohormones, mineral nutrients and transgenics. Plant Physiology and Biochemistry. vol 115: 126-140. doi: https://doi.org/10.1016/j.plaphy.2017.03.018.

Pérez-Rosés R, Risco E, Vila R, Peñalver P, Cañigueral S. 2016. Biological and nonbiological antioxidant activity of some essential oils. Journal of Agricultural and Food Chemistry. vol 64(23): 4716-4724.

doi: https://doi.org/10.1021/acs.jafc.6b00986.

Queiroz MS, Oliveira CE, Steiner F, Zuffo AM, Zoz T, Vendruscolo EP, Silva MV, Mello BFFR, Cabral RC, Menis FT. 2019. Drought stresses on seed germination and early growth of maize and sorghum. Journal of Agricultural Science. vol 11(2): 310-318. doi: https://doi.org/10.5539/jas.v11n2p310.

Riyadi E, Andarwulan N, Faridah DN. 2014. Profil senyawa volatil identitas nutmeg oil, patchouli oil dan fresh ginger oil asal Indonesia. Jurnal Mutu Pangan. vol 1(1): 19-25.

Setiawan, Tohari, Shiddieq D. 2012. Pengaruh Cekaman Kekeringan Terhadap Akumulasi Prolin Tanaman Nilam (Pogostemon cablin Benth.). Ilmu Pertanian (Agricultural Science). vol 15(2): 85-99. doi: https://doi.org/10.22146/ipas.2518.

Shaba EY, Mann A, Yisa J. 2014. Antimicrobial and cytotoxic activities and GC-MS analysis of phytocomponents of methanolic extract of Curculigo pilosa (Schum and Thonn) Engl.(Hypoxidaceae) rhizomes. Journal of Pharmaceutical Research International. vol 4(12): 1552-1567.

doi: https://doi.org/10.9734/BJPR/2014/10189.

Shrivastava G, Ownley BH, Augé RM, Toler H, Dee M, Vu A, Köllner TG, Chen F. 2015. Colonization by arbuscular mycorrhizal and endophytic fungi enhanced terpene production in tomato plants and their defense against a herbivorous insect. Symbiosis. vol 65(2): 65-74. doi: https://doi.org/10.1007/s13199-015-0319-1.

Swasono FG, Santoso M, Nihayati E. 2015. Pengaruh Cekaman Air Dan Kombinasi Pupuk Nitrogen Dan Kalium Terhadap Pertumbuhan Dan Kadar Minyak Atsiri Tanaman Serai Wangi (Cymbopogon nardus L.). Jurnal Produksi Tanaman. vol 3(7): 574-580.

Thara-Saraswathi KJ, Jayalakshmi NR, Vyshali P, Kameshwari S. 2011. Comparitive study on essential oil in natural and in vitro regenerated plants of Vetiveria zizanioides (Linn.) Nash. American-Eurasian Journal of Agricultural \& Environmental Sciences. vol 10(3): 458-463.

Turhadi T, Hamim H, Ghulamahdi M, Miftahudin M. 2019. Iron toxicity-induced physiological and metabolite profile variations among tolerant and sensitive rice varieties. Plant Signaling \& Behavior. vol 14(12): 1-13. doi: https://doi.org/10.1080/15592324.2019.1682829.

Umebese CE, Olatimilehin TO, Ogunsusi TA. 2009. Salicylic acid protects nitrate reductase activity, growth and proline in amaranth and tomato plants during water deficit. American Journal of Agricultural and Biological Sciences. vol 4(3): 224-229.

Wasson AP, Richards RA, Chatrath R, Misra SC, Prasad SS, Rebetzke GJ, Kirkegaard JA, Christopher J, Watt M. 2012. Traits and selection strategies to improve root systems and water uptake in waterlimited wheat crops. Journal of Experimental Botany. vol 63(9): 3485-3498. doi: https://doi.org/10.1093/jxb/ers111. 